\title{
IL-17A and Th17 Cells in Lung Inflammation: An Update on the Role of Th17 Cell Differentiation and IL-17R Signaling in Host Defense against Infection
}

\author{
Hsing-Chuan Tsai, Sharlene Velichko, Li-Yin Hung, and Reen Wu \\ Center for Comparative Respiratory Biology and Medicine, University of California, Davis, CA 95616, USA \\ Correspondence should be addressed to Reen Wu; rwu@ucdavis.edu
}

Received 16 March 2013; Accepted 27 June 2013

Academic Editor: Samuel Huber

Copyright (C) 2013 Hsing-Chuan Tsai et al. This is an open access article distributed under the Creative Commons Attribution License, which permits unrestricted use, distribution, and reproduction in any medium, provided the original work is properly cited.

\begin{abstract}
The significance of Th17 cells and interleukin- (IL-)17A signaling in host defense and disease development has been demonstrated in various infection and autoimmune models. Numerous studies have indicated that Th17 cells and its signature cytokine IL-17A are critical to the airway's immune response against various bacteria and fungal infection. Cytokines such as IL-23, which are involved in Th17 differentiation, play a critical role in controlling Klebsiella pneumonia (K. pneumonia) infection. IL-17A acts on nonimmune cells in infected tissues to strengthen innate immunity by inducing the expression of antimicrobial proteins, cytokines, and chemokines. Mice deficient in IL-17 receptor (IL-17R) expression are susceptible to infection by various pathogens. In this review, we summarize the recent advances in unraveling the mechanism behind Th17 cell differentiation, IL-17A/IL-17R signaling, and also the importance of IL-17A in pulmonary infection.
\end{abstract}

\section{Background and Overview of Th17 Cells and IL-17A}

$\mathrm{CD}^{+}{ }^{+} \mathrm{T}$ cells are central mediators of cellular immunity. For many years, $\mathrm{CD}^{+} \mathrm{T}$ cells were classified as either $\mathrm{T}$ helper (Th)1 or Th2 cells by their effector cytokines and functions $[1,2]$. Th1 cells, which express Interferon- $\gamma($ IFN- $\gamma$ ), are responsible for the control of cellular immune responses and tissue inflammation, whereas Th2 cells, which express IL-4, IL-5, and IL-13, are responsible for the regulation of humoral immunity and allergic disease. The discovery of Th17 cells revolutionized our concept of immunopathology and immune regulation. Th17 cells produce proinflammatory cytokines $[3,4]$ such as IL-17A, IL-17F, IL-22, IL-26, tumor necrosis factor- $\alpha$ (TNF- $\alpha$ ), chemokine (C-C motif) ligand 20 (CCL20) [5], and granulocyte macrophage colonystimulating factor (GM-CSF) [6]. Although these cytokines all have proinflammatory features, they act on different target cells and therefore contribute to different diseases [7-9]. Th17 cells have been implicated in a wide variety of inflammatory conditions, such as autoimmune diseases, chronic inflammation, and pathogen infection [10].
The differentiation of naive T cells to Th17 cells is regulated by multiple signals. The engagement of TCR receptors (Signal 1) and costimulatory molecules (Signal 2) initiates naive $\mathrm{T}$ cell differentiation, and then cytokines produced by the innate immune system (Signal 3) direct the differentiation to particular Th subsets. The proinflammatory cytokines IL-1 $\beta$, IL-6, IL-21, and IL-23, and the anti-inflammatory cytokine, transforming growth factor- $\beta$ (TGF- $\beta$ ), coordinate to trigger Th17 cell differentiation in a RAR-related orphan receptor- $\gamma \mathrm{t}(\mathrm{ROR} \gamma \mathrm{t})$ dependent manner $[11,12]$.

IL-17A is the signature effector cytokine of Th17 cells and contributes to Th17-mediated diseases. Although first identified in $\mathrm{CD}^{+} \mathrm{T}$ cells, IL-17A can also be produced by $\mathrm{CD}^{+} \mathrm{T}$ cells [13] and innate cells, such as $\gamma \delta \mathrm{T}$ cells [14, 15], NK1.1-iNKT cells [16], neutrophils [17], and also innate lymphoid cells (ILCs) [18-20]. IL-17A appears to act primarily on nonhematopoietic cells such as endothelial cells [21, 22], epithelial cells [23-25], and fibroblasts [26, 27], due to the restricted expression of one of its receptor subunits, IL-17RC $[28,29]$. Systemically, IL-17A and IL-17F have been reported to play a pathogenic role in certain autoimmune diseases, including multiple sclerosis and rheumatoid arthritis [30-32]. 
However, its role at mucosal surfaces appears to be dualistic. While high expression of IL-17A has been linked to inflammatory diseases of the mucosal surface, such as asthma, cystic fibrosis, and chronic obstructive pulmonary disease (COPD) in the airway, as well as inflammatory bowel disease, it appears to play an important protective role against infection, particularly by extracellular bacterial pathogens $[26,33-$ 40]. Here, we will summarize recent studies on Th17 cell differentiation as well as IL-17R signaling and highlight the role of Th17/IL-17A in pulmonary infection. The roles of innate IL-17A-producing cells in the pulmonary infection will also be discussed.

\section{Factors Involved in Th17 Cell Development}

Although IL17A production by $\mathrm{CD}^{+} \mathrm{T}$ cells was first described 20 years ago, Th17 cells were not recognized as a distinct $\mathrm{CD}^{+}$cell lineage until 2005 [41, 42]. Th17 cell differentiation has primarily been characterized in the murine system [4]. In mice, IL-6 and TGF- $\beta$ initiate Th17 cell differentiation by activating STAT3 and inducing IL23R expression. IL-23 is then responsible for Th17 cell maintenance and expansion [11, 43-45]. In addition, Th17 cells also secrete IL-21, an autocrine mechanism to sustain and promote their own differentiation via a STAT3-mediated manner $[46,47]$. IL- $1 \beta$ was initially thought to play an accessory role in mouse Th17 cell differentiation but recently it has been demonstrated to play a critical role in the early differentiation stages of mouse Th17 cells [48].

However, human Th17 cell differentiation is intrinsically different from murine Th17 because IL-23R is already expressed on human naive $\mathrm{T}$ cells, prior to differentiation [49]. IL-1 $\beta$ and IL-23 are sufficient to induce human Th17 cells from $\mathrm{CD}^{+}{ }^{+} \mathrm{CD} 161^{+}$cells derived from umbilical cord blood [50], whereas the role of TGF- $\beta$ has been controversial $[51,52]$. Recently, it has become clear that TGF- $\beta$ plays an auxiliary role in the suppression of Th1 and Th2 cells [53]. TGF- $\beta$ orchestrates with proinflammatory cytokines to promote Th17 cell differentiation in a dosage-dependent manner [54]. At low concentrations, TGF- $\beta$ induces ROR $\gamma \mathrm{t}$ expression and promotes the expression of ROR $\gamma$ t-inducing genes. However, at high concentrations, robust forkhead box P3 (FOXP3) expression induced by TGF- $\beta$ suppresses Th17 cell differentiation by antagonizing ROR $\gamma \mathrm{t}$ function [55]. In our laboratory, we also found that human naive $\mathrm{T}$ cells responded differentially to the concentration of TGF- $\beta$, depending on the individual donor (Tsai, HC, unpublished data).

Through cytokine signaling or environmental factors, multiple transcription factors (TFs) are induced to drive Th17 differentiation [56], such as STAT3, Runt-related transcription factor 1 (Runxl) [57], ROR $\alpha$, ROR $\gamma$ t, aryl hydrocarbon receptor (AHR), interferon regulatory factor 4 (IRF4), and basic leucine zipper transcription factor (BATF) [58]. These TFs not only regulate IL-17A expression but the expression of other Th17-associated genes as well. The expression of Th17-signature cytokines, such as IL-17A, IL-17F, and IL-22, is differentially regulated by Th17-lineage transcription factors.
ROR $\gamma t$ is the "master regulator" for Th17 differentiation and also directly binds to cis-regulatory elements of the IL17A/F gene $[59,60]$. AHR responds to a physiological ligand, tryptophan photoproduct 6-formylindolo[3,2-b]carbazole (FICZ), to promote both IL17A and IL22 expression [61]. The expression of IL17A and IL22 is differentially regulated by TGF$\beta$. IRF4 regulates not only IL17A expression $[62,63]$ but also Th2 cytokine expression [64]. Thus, IRF4 may regulate Th2 and Th17 differentiation by interacting with different transcription factors. The STAT family also plays a vital role in Th17 differentiation. STAT3 is activated by Th17 promoting cytokines (IL-6, IL-21, and IL-23) and directly binds to the promoter of the Il17a-Illif locus, as well as the Il21 gene [45]. On the other hand, other Stat molecules, including Statl, activated by IL-27 $[65,66]$, and Stat $5 a / b$, activated by IL-2 [67], play inhibitory roles in Th17 differentiation. Recently, the reciprocal action of STAT3 and STAT5 on the Il17a loci has been reported [68]. STAT3 and STAT5 have been demonstrated to compete for the same binding sites of the Il17a-Il17f locus [68]. The relative ratio of STAT3/STAT5 affects the intensity of IL-17A and IL-17F expression in Th17 cell differentiation [68].

The differential regulation of Th17 cytokines also reflects their different roles in physiological conditions and disease pathogenesis [7, 69]. For instance, Yang and colleagues [8] suggested that IL-17A was required to induce EAE, whereas IL-17F was required to induce airway neutrophilia in allergic airway animal models. Additionally, it was demonstrated that IL-22 but not IL-17A was required to protect mice from Citrobacter rodentium infection [70].

The understanding of Th17 cell differentiation has been applied to the development of therapies targeted to Th17mediated autoimmune diseases [71]. Synthetic or natural forms of ROR $\gamma \mathrm{t}$ inverse agonists have been studied to suppress IL-17A expression. SR1001, one of the inverse agonists, was shown to be efficacious in the experimental autoimmune encephalomyelitis (EAE) model in rodents [72]. The comprehensive regulation of different Th17-related gene expression urgently needs to be studied for the development of more specific therapy in diseases.

\section{IL17 Family and Their Receptors}

Interleukin-17A was first identified in activated rodent $\mathrm{T}$ lymphomas, termed CTLA-8, and subsequently identified in humans in 1995 [73, 74]. At the time, it was noted that IL17A had a unique structure among the interleukin cytokines. Five related cytokines were subsequently discovered through genome database searches and degenerative RT-PCR techniques [75]. The IL-17A cytokine family members (IL-17A, IL-17B, IL-17C, IL-17D, IL17E/IL-25, and IL-17F) share 20$50 \%$ homology at the amino acid level [76]. IL-17F is the most closely related member to IL-17A, and the IL-17F gene is located in the same chromosomal region as $I l 17 a$ in humans $(6 \mathrm{p} 12)$. The resultant protein is approximately $44 \%$ homologous to the IL-17A protein and forms as homodimers and heterodimers with IL-17A, and binds a shared receptor heterodimer, IL-17RA/IL-17RC [28, 77-81]. IL-25 is the most 
distantly related member of the IL-17 family, with only $20 \%$ homology to the IL-17A protein. IL-25 also binds to a different receptor heterodimer, IL-17RA/IL-17RB [82]. IL-17B, IL-17C, and IL-17D are less well characterized. IL-17B and IL-17C were reported to be associated with TNF- $\alpha$ production and inflammatory arthritis [83]. In recent studies, IL-17C has been demonstrated to bind to IL-17RA/RE and has similar biological functions to IL-17A [84-86]. Similar to IL-17A, Actl activation is required for these IL-17C-induced responses [84]. In an EAE model, IL-17C deficient mice exhibited less severe disease; this phenomenon demonstrates the pathogenic role of IL-17C in EAE. IL-17C also promoted Th17 responses via IL-17RE signaling in an EAE model [84]. IL-17C was reported to induce the expression of cytokines, chemokines, and antimicrobial peptides by epithelial cells. Overall, IL-17C is important in host defenses against pathogens $[85,86]$. IL$17 \mathrm{D}$ is preferentially expressed by the nonimmune cells that compose skeletal muscle, adipose and lung tissue. It induces IL-6, IL-8, and GM-CSF expression in endothelial cells and suppresses hematopoiesis [87]. Since Th17 cells express only IL-17A and IL-17F, we will highlight their roles and what is known regarding IL-17R signaling in the following discussion.

3.1. IL-17R Signaling. The IL-17R family is composed of five receptors (IL-17RA-IL-17RE) and the ligand-receptor pairing is not completely understood for all members. Extensive biochemical studies have been executed to characterize IL17 binding to its receptors [88]. Briefly, IL-17A and IL-17F can form homodimers or heterodimers (IL-17A/A, IL-17A/F, IL17F/F) to bind to a heteromeric receptor complex composed of IL-17RA and IL-17RC. Surface plasmon resonance (SPR) studies revealed that the different dimers have different affinities for the receptor subunits [28, 77, 89]. X-ray crystallographic, fluorescence resonance energy transfer (FRET) and SPR analyses suggest that IL-17RA homodimers are preassembled as "inactive" receptors on the cell membrane in the absence of ligand binding and that ligand binding shifts the favorability towards the formation of an IL-17RA and IL17RC heterodimer [78, 79, 89].

In 2003, a bioinformatics approach was used to identify a conserved domain present in IL-17RA and the other IL-17 receptor family members, that was distantly related to the TIR domain in Toll-like receptor (TLR) and IL-1 receptor (IL-1R) signaling [90]. Because of the similarity to the TIR domain, this domain, termed the SEFIR (SEF/IL17R) domain, was proposed to belong to a superfamily with the TIR domain, termed the STIR superfamily. In TLR signaling, the TIR domain mediates the binding of adaptor proteins such as MyD88 and Mal/TRAP to the receptor via homotypic interactions between their respective TIR domains $[91,92]$. However, the SEFIR domain lacks the TIR box 3 subdomain and the BB-loop [90], which are critical for the protein-protein interaction of TLR signaling [93]. MyD88 and $\mathrm{Mal}$ are not thought to be involved in IL-17 signaling. Although lacking BB loop, a TIR-like loop (TILL) at the $\mathrm{C}^{\prime}$ terminal side of SEFIR domain in IL17RA, which sequence is homologous to $\mathrm{BB}$ loop, may provide the surface for protein-protein interaction $[94,95]$. Another SEFIR-domain containing protein, Actl (also known as CIKS) was later identified as an essential mediator of IL-17 signaling via its interaction with IL-17R $[28,96]$. The shRNA knockdown of Actl expression was shown to attenuate IL-17A signaling in mouse embryonic fibroblasts (MEFs) [97]; likewise, Actl-null mouse embryonic fibroblasts were shown to be unresponsive to IL-17A stimulation [98]. The direct interaction of Actl and IL-17RA was demonstrated through coimmunoprecipitation experiments and shown to be dependent on the SEFIR domain $[97,98]$. Act1 $\mathrm{KO}$ mice were shown to have reduced EAE and DSS-colitis induced disease severity, similar to IL17A KO mice [98]. It was subsequently shown that Actl can also interact with IL-17RC, as well as IL-17RB, in a SEFIR domain dependent manner $[28,96]$. Actl was also shown to be an essential mediator of IL-25 signaling [96]. Now, it is clear that the CC' loop of the SEFIR domain is critical for the SEFIR-SEFIR binding [99]. In addition to the SEFIR domain, it has recently been shown that the C-terminal region beyond the SEFIR domain, for both IL-17RA and IL-17RC, is also necessary for the full activity of IL-17A [100].

Act 1 has a TNFR-associated-factor- (TRAF-) binding domain at the amino terminus and a coiled-coil domain containing the SEFIR domain at the carboxyl terminus. TRAF3 and TRAF6 have both been shown to associate with IL-17RA. TRAF6 associates indirectly with IL-17RA through Actl and, in most cases, positively mediates IL-17A signaling [101]. Recently, TRAF3 has been shown to interact directly with IL-17RA, via a TRAF-binding domain at the distal Cterminus of the receptor's intracellular domain, as well as with the intracellular domain of IL-17RC [102]. Most intriguingly, TRAF3 has been shown to inhibit IL-17A signaling and IL-17 mediated EAE, the first demonstration of a negative regulatory feedback mechanism for IL-17A. Although the mechanism of this negative regulation is not completely clear, it may in part be due to the fact that TRAF3 binding to the distal domain of IL-17RA appears to interfere with ActlTRAF6 binding to the SEFIR domain of IL-17RA.

In addition, Actl is also a U-box type E3 ubiquitin ligase and it ubiquitinates TRAF6. The TRAF6 ubiquitination is required for the IL-17A-induced activation of nuclear factor$\kappa \mathrm{B}(\mathrm{NF}-\kappa \mathrm{B})[103]$. The canonical NF- $\kappa \mathrm{B}$ pathway is the most well-described downstream signaling pathway of IL-17A. Indeed, IL-17A induces phosphorylation of p65 at $\mathrm{Ser}^{536}$; our lab and others have demonstrated p65 and p50 translocation into the nucleus following IL-17A stimulation [23, 104]. Mutation of NF- $\kappa \mathrm{B}$ binding sites in the promoter region of the IL-17A target gene, human beta defensin 4 (DEFB4), severely attenuates promoter activation in response to IL-17A stimulation in airway epithelial cells [105]. NF- $\kappa \mathrm{B}$ is also the major pathway responsible for IL-17 induced early response genes ( $<4$ hours) [104]. However, NF- $\kappa$ B cannot be the sole pathway responsible for IL-17 A's effects. For example, in comparison to "classical" NF- $\kappa$ B activating cytokines such as TNF- $\alpha$ and IL$1 \beta$, activation of p65-p50 NF- $\kappa$ B by IL-17A is relatively weak; yet, induction of DEFB4 in airway epithelial cells by IL-17A is much greater than either TNF- $\alpha$ or IL-1 $\beta$ [23]. It is plausible that it is the synergistic induction of multiple transcription 
factors including NF- $\kappa \mathrm{B}$, which is responsible for IL-17A's effects. Indeed, other transcription factors, such as AP-1 and $\mathrm{C} / \mathrm{EBP} \delta$ (CCAAT/enhancer binding protein $\delta$ ), have been shown to be activated by IL-17A $[94,106]$. In addition, all three mitogen activated protein (MAP) kinase pathways, JNK (JUN Ntermainal kinase), ERK (extracellular signal-related kinase) and p38, have been described in the literature as being activated by IL-17A [107]. The relative contribution of the individual pathways appears to depend both on the cell type being studied, as well as on the target gene being studied. In airway epithelial cells specifically, our lab has demonstrated that JAK1/2 and PI3-kinase, Act1/TRAF6/TAK1/NF- $\kappa$ B, and MEK1/2 (MAP kinase kinase1/2)-ERK are all involved in IL17 mediated gene expression, and that the pathway involved varied depending on the target gene in question [23, 108110]. Other labs have shown the involvement in p38 in IL-17 mediated IL- 6 and IL-8 gene expression by airway epithelial cells as well [111, 112]. Actl has been shown to be necessary for IL-17A induced NF- $\kappa \mathrm{B}$ and $\mathrm{C} / \mathrm{EBP} \delta$ activation, as well as JNK and p38 activation [98]. Interestingly, IL-17 induced ERK activation appears to be Actl independent $[98,104]$.

IL-17A utilizes two different methods to increase target gene expression. The first is by transcriptional activation; we have previously demonstrated that this is the case for DEFB4 and CCL20 induction by IL-17A in airway epithelial cells using promoter-luciferase reporter assays [105, 109]. The second method of increasing gene expression is by stabilization of the target mRNA via a tristetrapolin/AUUUAindependent mechanism. This has been demonstrated in HeLa cells for both IL-17A induced CXCL1 and NFIKBZ expression [113-115]. The mRNA stabilization pathway appears to be dependent on Act1, but independent of TRAF6, the first demonstration of Actl-dependent, TRAF6-independent IL-17 signaling.

More fine-tuned control of Actl and IL-17R signaling has been recently described. Actl exists in multiple phosphorylated forms, which display different functions. In 2010, Actl was found to be phosphorylated upon IL-17A stimulation [116]. The inducible kinase IKKi (inducible inhibitor of NF- $\kappa \mathrm{B}(\mathrm{I} \kappa \mathrm{B})$ kinase; also known as IKKe) forms a complex with Actl and IL-17R and catalyzes the phosphorylation of Actl at Ser ${ }^{311}$, adjacent to its putative TRAFbinding motif [117]. The phosphorylated form of Actl appears to have different affinities to various TRAF proteins. Mutation of IKKi or substitution of S311A of Actl abolished Actl's interaction with TRAF2 and TRAF5, but not TRAF6. This phosphorylated form of Actl has also been shown to be important for IL17R-Act1-TRAF2/5-mediated mRNA stability. Neither IKKi nor phosphorylation of $\mathrm{Ser}^{311}$ on Act1 is required for IL-17A-induced activation of NF- $\kappa \mathrm{B}$. However, IKKi is still responsible for the IL-17A-induced expression of pro-inflammatory genes ( $\mathrm{Cxcl1}, \mathrm{Cxcl} 2, \mathrm{Tnf}, \mathrm{Il} 6$, and Csf3), resulting in neutrophilia and pulmonary inflammation. A different story is found for other phosphorylated forms of Actl. Three additional serines on human Actl (Ser ${ }^{162}$ (not phosphorylated by IKKi), Ser ${ }^{220}$, and Ser ${ }^{233}$ ) and mouse Actl $\left(\operatorname{Ser}^{147}\right.$, Ser $^{209}$, and Ser $^{222}$ ) are phosphorylated by IKKi and TBK1 (TANK binding kinase 1, another IKK-related kinases)
[118]. TBK1 and IKKi play redundant roles in the phosphorylation of these three sites sites and act to suppress IL$17 \mathrm{~A}$-induced activation of $\mathrm{NF}-\kappa \mathrm{B}$. In this study, the authors reported that IL-17A-induced Actl phosphorylation is TRAF6-dependent and serves to suppress IL-17A-induced gene production, such as $c c l 20, c c l 3, c x c l 2$, and $K C$. Interstingly, IKKi appears to regulate IL-17-induced Actl phosphorylation at different sites via both TRAF6-dependent and TRAF6-independent pathways. More research regarding kinase-mediated Actl phosphorylation and their specific roles in IL-17A-induced inflammatory response is needed.

\subsection{Beyond IL-17RA: IL17-RC and IL-17RD. IL-17RA serves} as the common receptor for IL-17 family members, in a manner similar to that of gp130 in IL-6 family signaling. IL17RA is the most well-characterized IL-17R subunit because of its critical role in IL-17 and IL-25 induced signaling. However, in addition to IL-17RA, IL-17RC and IL-17RD have also been shown to have distinct functions in IL-17-mediated signaling.

IL-17RC was identified by a homology search of a mammalian expressed sequence tag database and found to share $22 \%$ sequence homology with IL-17RA $[29,119]$. Unlike IL-17RA, IL-17RC has no obvious TILL structure in its cytoplasmic domain; whether Act1, TRAF6, or other signaling intermediates are recruited to IL-17RC are unclear [88]. Although the $\mathrm{CC}^{\prime}$ loop, which is responsible for the interaction of Act1/IL-17RA, is also conserved in IL-17RC [99], no direct evidence supports the interaction of Actl and IL-17RC. Intriguingly, IL-17RA and IL-17RC have strikingly distinct tissue expression patterns. In contrast to IL-17RA, IL-17RC is preferentially expressed in nonimmune cells of the prostate, liver, kidney, thyroid, joints, and lung [77, 119121]. In term of biological functions, IL-17RA and IL-17RC have differential affinity to IL-17A and IL-17F $[28,77,89]$. In humans, IL-17RA binds to IL-17F with extremely low affinity but IL-17RC has higher affinity binding to IL-17F than IL-17A. In mice, IL-17RA binds both IL-17A and IL-17F but IL-17RC only binds to IL-17F. Therefore, both IL-17RA and IL-17RC are required for IL-17F signaling. With the exception of IL17RA, IL-17RC has various spliced isoforms and the affinity of IL-17RC splice variants to IL-17A and IL-17F are variable $[29,77]$. Since some IL-17RC variants have no affinity to both IL-17A and IL-17F, it is possible that IL-17RC may have other ligands as well. The existence of soluble forms of IL-17RC have been demonstrated in humans but their physiological roles as well as that of the other variants are still unclear. Soluble IL-17RC has been proposed as a decoy receptor to inhibit IL-17R signaling but no evidence supporting this hypothesis yet exists [119]. Although little is known about exactly how IL-17RC participates in signaling, the cytoplasmic tail of the extended SEFIR domain of IL-17RC is essential for functional IL-17A-dependent signaling and IL-17RC knockout mice are susceptible to Candida albicans [100]. IL-17RC has also been reported to play a role in a number of human diseases. The levels of IL-17A, IL-17F, IL-17RA, and IL-17RC are also high in the sera and inflamed synovium of patients with rheumatoid arthritis [122-124]. However, the specific role of IL-17RC in these diseases has not been clarified. 
IL-17RD was also known as SEF (similar expression to the FGFR) due to its similar expression pattern to the fibroblast growth factor receptor during zebrafish development [90]. The role of IL-17RD in FGF signaling and development is beyond the scope of this review. Previous findings showed that basal IL-17RD expression is higher than IL-17RA; in addition, IL-17A stimulation enhances the expression of other IL-17R family members, but not IL-17RD expression [125]. It has been indicated that IL-17RD may interact with IL17RA to mediate IL-17A signaling, but the mechanism by which the interaction occurs has not yet been elucidated [126]. Recently, it has been reported that the orphan receptor IL-17RD differentially regulates IL-17A-induced NF- $\kappa$ B and p38 MAPK signaling. IL-17RD utilizes its SEFIR domain to sequester Actl from interacting with IL-17RA and TRAF6, thereby negatively regulating NF- $\kappa \mathrm{B}$ signaling. IL-17RD may therefore act as a basal braking system to prevent IL-17A mediated NF- $\kappa$ B activation. Conversely, IL-17RD promotes IL-17A-induced activation of p38 MAPK to induce the expression of the neutrophil-attractive chemokine, CXCL2, so the net effect of IL-17RD in IL-17A-mediated neutrophilia is unclear [127].

\section{IL-17A-Induced Gene Expression in the Airway}

IL-17A acts on a variety of cell types [128]. The best characterized IL-17A-targeted cells are nonimmune cells, such as epithelial cells and mesenchymal cells. In addition, IL-17A also acts on some immune cells. Immune cells express IL17RA but not IL-17RC, and some studies have described that IL-17 synergized with B cell activation factor to promote B cell survival and proliferation [129] and that IL-17A induced matrix metalloproteinase 9 (MMP-9) expression in monocytes/macrophages [130, 131]. Here, we focus our discussion on the recent discoveries regarding IL-17A-mediated gene expression in airway epithelial cells and other cells in the airway.

In the context of airway epithelial cells, IL-17A-targeted genes can be roughly divided in three different categories: antimicrobial molecules, chemokines/cytokines, and adhesion molecules. A number of proteins with antimicrobial properties have been described as being upregulated by IL-17A, including CCL20, DEFB4, MUC5B/AC, S100A7, S100A8, and LCN2/24p3 (lipocalin 2) [25]. These proteins are important for the protective effect of IL-17 against extracellular pathogens. In addition, IL-17 A stimulates the production of a number of chemokines and cytokines by airway epithelial cells. Some, such as CXCL1, CXCL2, IL-6, IL-8, KC, and GM-CSF, play a critical role in IL-17A's ability to recruit neutrophils to the airway [118, 125, 132-134]. Others, such as CCL20 and IL-19, have the ability to recruit or influence the differentiation of cells of the adaptive immune system, such as Th17 and Th2 cells, respectively $[135,136]$. Additionally, in vitro studies showed that IL-17A induces CCL28 expression in the human airway epithelium, which causes the migration of IgE-secreting B cells [137]. Finally, it has been demonstrated that IL-17A can enhance the proliferation of airway epithelial cells, although the target genes responsible for this effect have yet to be identified [138]. IL-17A can also increase the expression of ICAM-1 in airway epithelial cells and claudin-1 and claudin-2 in intestinal epithelial cells, important adhesion, and cell junction molecules $[139,140]$.

Besides airway epithelial cells, IL-17A also directly acts on airway smooth muscle (ASM) [141] and lung microvascular endothelial cells (LMVECs) [142-144]. IL-17A directly enhances ASM contraction through the IL-17RA/RC complex on the basis of a NF- $\kappa \mathrm{B} / \mathrm{RhoA} / \mathrm{ROCK} 2$ signal cascade in murine models of house dust mite-induced and ovalbumininduced asthma. IL-17A mediated ASM contraction has also been confirmed in human lung tissue [141]. IL-17RA and IL17RC are also expressed on the surface of LMVECs and IL17A significantly induces CXCL1 production in LMVECs. In synergy with IL- $1 \beta$ and TNF- $\alpha$, IL-17 also enhances CXCL5 and CXCL8 expression in these cells [144].

One of the most striking features of IL-17A signaling is its ability to synergize with other proinflammatory cytokines, as well as with TLR signaling pathways. In the literature, it has been reported that TNF- $\alpha$, IL-1 $\beta$, IL-22, Oncostatin M, IFN $\gamma, \mathrm{BAFF}$, and CD40L can all synergize with IL-17A to upregulate IL-17A target genes or their respective target genes $[129,139,145-147]$. In addition, IL-17A also synergizes with TLR2 and TLR4 ligands to increase IL-8 production in a human cystic fibrosis bronchial epithelial cell lines [148]. In an in vivo context, this may be where IL-17A induces its most potent effects, within the cytokine milieu of an inflammatory setting to further potentiate the inflammatory response. The mechanism by which this synergism occurs is not yet known, but deserves further study.

\section{IL-17A in Pulmonary Infection}

Numerous studies have identified a protective role of IL$17 \mathrm{~A}$ in immunity against various infections, including the infection of intracellular [133, 149-151] and extracellular bacteria [152, 153], fungi $[154,155]$, and even parasites [156]. In murine models of airway infection, IL-17A has been shown to play a critical role in the defense against extracellular bacterial pathogens, such as K. pneumonia, and Pseudomonas aeruginosa $[152,153,157]$. It has also been reported to play a protective role against intracellular bacterial pathogens, such as Chlamydia muridarum, and Mycoplasma pneumonia. Although the exact mechanism of this protection is unclear, the deficiency of IL-17 signal or other Th17associated cytokines in various infection models has shown that neutrophil recruitment is impaired in infected tissue, which is also linked to the reduction of CXC chemokines expression [133, 149-151]. Additionally, Th17 cell response has also been reported to contribute to the mucosal vaccine response against pathogens $[158,159]$. Mice vaccinated with antigen from Mycobacteria tuberculosis $(M t b)$ provoke a Th17 response, and the CXCL-13 induction by IL-17A is critical in the protection against Mtb infection [159]. IL-17A has also been reported to play a protective role at other mucosal surfaces, with other types of pathogens as well, Candida albicans infection in the oral cavity and Salmonella 
dissemination in the intestines $[155,160]$. Interestingly, one intracellular respiratory pathogen, Chlamydia pneumoniae, has developed a defense against IL-17A signaling. It encodes a protein, CP0236, which binds to the essential IL-17 signaling mediator protein Actl (also known as CIKS and TRAF3IP2) and sequesters it in bacterial inclusion bodies, leaving it unavailable to mediate IL-17 signaling [161]. The adaption of anti-IL-17 strategies by bacterial pathogens underlines the importance of IL-17A signaling in host defense.

\section{Innate IL-17A-Producing Cells in Host Defense and Pulmonary Infection}

The significance of IL-17A production by innate immune cells in host defense against infection as well as development of autoimmune diseases has been demonstrated and reviewed [162-164]. Cells of the innate immune system are abundant in the skin and at mucosal surfaces and respond rapidly to pathogenic infection, providing the first line of defense. Interestingly, innate IL-17A-producing cells share some characteristics with Th17 cells. For instance,s $\gamma \delta \mathrm{T}$ cells respond to IL-1 $\beta$, IL-18, and IL-23 [165-167] and share some common transcription factors with Th17 cells, such as AHR, ROR $\gamma t$, and STAT3 $[59,168,169]$. ILCs can be divided into three functionally distinct types; $\mathrm{ROR} \gamma \mathrm{t}$ is required for the differentiation and maintenance of type 3 ILCs $[170,171]$. These ROR $\gamma \mathrm{t}+$ ILCs express either IL-17A or IL-22, and some of them express both IL-17A and IL-22 [18-20, 172, 173]. iNKT cells constitutively express IL-23R and $\operatorname{ROR} \gamma \mathrm{t}[174,175]$ and produce IL-17A upon stimulation by IL-1 $\beta$, IL-18, IL-23, and TGF- $\beta[174,176,177]$; however, unlike Th17 cells, iNKT cells do not respond to IL-6 stimulation [174].

Early IL-17A production by these innate cells provides an initial response to pathogens to recruit neutrophils within 4-8 hours after infection. In the lung, $\gamma \delta \mathrm{T}$ cells have been demonstrated to be the major source of early IL$17 \mathrm{~A}$ production in response to some infections, such as $K$. pneumonia [178], M. tuberculosis [15, 179], and Mycobacterium bovis [180]. In the $M$. bovis-infected mouse model, the IL-17A secretion by $\gamma \delta \mathrm{T}$ cells is essential for mature granuloma formation and resolution of infection [180]. IL$17 \mathrm{~A}$-producing iNKT cells comprise up to $40 \%$ of pulmonary iNKT cells [16] and may also be responsible for the infection with Streptococcus pneumonia [181]. In addition, early IL-17A responses may also promote subsequent adaptive immune responses. IL-17A has been reported to induce chemokines to attract Th1 cells into the lung $[182,183]$, and this secondary response may provide more efficient pathogen clearance. In an EAE model, the depletion of $\gamma \delta \mathrm{T}$ cells is responsible for the development of fewer antigen-specific Th17 cells [165]. Therefore, innate IL-17-producing cells may also enhance or direct the development of later Th17 responses.

\section{Summary and Perspectives}

To summarize, Th17 effector cytokines such as IL-17 are differentially regulated via multiple transcription factors and play different roles in diseases. Through multiple IL-17R subunits and the posttranslational modification of Actl, IL17A mediates tissue inflammation and host defense in many facets of signaling regulation. IL-17A induced production of pro-inflammatory cytokines, chemokines, and antimicrobial peptides by multiple cell types in the airway is critical for mounting successful host defense against pathogens. Due to advances in Th17/IL17A research, efforts are now underway to apply some of these findings to the clinical setting, particularly in the setting of autoimmune diseases. A delicate balance is needed to dampen the pathogenic effects of Th17/IL-17A in inflammatory and autoimmune diseases while maintaining the important role it plays in airway host defense. A more comprehensive understanding of Th17 cell differentiation and their functions is urgently needed to provide specific molecular targets to constrain diseasespecific cytokine production from Th17 cells but retain other functions of Th17 cells. In addition, the role of innate IL17A-producing cells in contributing to the resolution of infection and the progression of inflammation cannot be overlooked. Studies on the regulation mechanism of innateIL-17-producing cells and the clinical relevance of these cells are still limited. A comprehensive understanding of these innate IL-17 cells may be useful in the development of disease therapy. Additionally, a thorough knowledge of cell-type specific IL-17 signaling mechanism also provides alternative therapeutic potentials in IL-17A-mediated diseases.

\section{Conflict of Interests}

The authors have no direct financial interest or relationship to the subject matter of this report.

\section{Acknowledgments}

The authors thank Sarah Statt for her editing. This study was supported by HL077902, HL096373, and HL097087 from $\mathrm{NIH}$.

\section{References}

[1] T. R. Mosmann and R. L. Coffman, "TH1 and TH2 cells: different patterns of lymphokine secretion lead to different functional properties," Annual Review of Immunology, vol. 7, pp. 145-173, 1989.

[2] C. Dong and R. A. Flavell, “Th1 and Th2 cells," Current Opinion in Hematology, vol. 8, no. 1, pp. 47-51, 2001.

[3] N. J. Wilson, K. Boniface, J. R. Chan et al., "Development, cytokine profile and function of human interleukin 17producing helper T cells," Nature Immunology, vol. 8, no. 9, pp. 950-957, 2007.

[4] C. Dong, "TH17 cells in development: an updated view of their molecular identity and genetic programming," Nature Reviews Immunology, vol. 8, no. 5, pp. 337-348, 2008.

[5] K. Hirota, H. Yoshitomi, M. Hashimoto et al., "Preferential recruitment of CCR6-expressing Th17 cells to inflamed joints via CCL20 in rheumatoid arthritis and its animal model," Journal of Experimental Medicine, vol. 204, no. 12, pp. 28032812, 2007. 
[6] M. El-Behi, B. Ciric, H. Dai et al., "The encephalitogenicity of TH 17 cells is dependent on IL-1- and IL-23-induced production of the cytokine GM-CSF," Nature Immunology, vol. 12, no. 6, pp. 568-575, 2011.

[7] R. Spolski and W. J. Leonard, "Cytokine mediators of Th17 function," European Journal of Immunology, vol. 39, no. 3, pp. 658-661, 2009.

[8] X. O. Yang, H. C. Seon, H. Park et al., "Regulation of inflammatory responses by IL-17F," Journal of Experimental Medicine, vol. 205, no. 5, pp. 1063-1075, 2008.

[9] H.-L. Ma, S. Liang, J. Li et al., "IL-22 is required for Th17 cellmediated pathology in a mouse model of psoriasis-like skin inflammation," Journal of Clinical Investigation, vol. 118, no. 2, pp. 597-607, 2008.

[10] P. Miossec, T. Korn, and V. K. Kuchroo, "Interleukin-17 and type 17 helper T cells," The New England Journal of Medicine, vol. 361, no. 9, pp. 848-898, 2009.

[11] M. Veldhoen, R. J. Hocking, C. J. Atkins, R. M. Locksley, and B. Stockinger, "TGF $\beta$ in the context of an inflammatory cytokine milieu supports de novo differentiation of IL-17-producing $\mathrm{T}$ cells," Immunity, vol. 24, no. 2, pp. 179-189, 2006.

[12] E. de Jong, T. Suddason, and G. M. Lord, "Translational minireview series on Th17 Cells: development of mouse and human T helper 17 cells," Clinical and Experimental Immunology, vol. 159, no. 2, pp. 148-158, 2010.

[13] K. I. Happel, M. Zheng, E. Young et al., "Cutting edge: roles of toll-like receptor 4 and IL-23 in IL-17 expression in response to Klebsiella pneumoniae infection," Journal of Immunology, vol. 170, no. 9, pp. 4432-4436, 2003.

[14] M. A. Stark, Y. Huo, T. L. Burcin, M. A. Morris, T. S. Olson, and K. Ley, "Phagocytosis of apoptotic neutrophils regulates granulopoiesis via IL-23 and IL-17," Immunity, vol. 22, no. 3, pp. 285-294, 2005.

[15] E. Lockhart, A. M. Green, and J. L. Flynn, "IL-17 production is dominated by $\gamma \delta \mathrm{T}$ cells rather than CD4 T cells during Mycobacterium tuberculosis infection," Journal of Immunology, vol. 177, no. 7, pp. 4662-4669, 2006.

[16] M.-L. Michel, A. C. Keller, C. Paget et al., "Identification of an IL-17-producing NK1.1neg iNKT cell population involved in airway neutrophilia," Journal of Experimental Medicine, vol. 204, no. 5, pp. 995-1001, 2007.

[17] S. Ferretti, O. Bonneau, G. R. Dubois, C. E. Jones, and A. Trifilieff, "Il-17, produced by lymphocytes and neutrophils, is necessary for lipopolysaccharide-induced airway neutrophilia: IL-15 as a possible trigger," Journal of Immunology, vol. 170, no. 4, pp. 2106-2112, 2003.

[18] T. Cupedo, N. K. Crellin, N. Papazian et al., "Human fetal lymphoid tissue-inducer cells are interleukin 17-producing precursors to $\mathrm{RORC}^{+} \mathrm{CD} 127^{+}$natural killer-like cells," Nature Immunology, vol. 10, no. 1, pp. 66-74, 2009.

[19] H. Takatori, Y. Kanno, W. T. Watford et al., "Lymphoid tissue inducer-like cells are an innate source of IL-17 and IL-22," Journal of Experimental Medicine, vol. 206, no. 1, pp. 35-41, 2009.

[20] S. Buonocore, P. P. Ahern, H. H. Uhlig et al., "Innate lymphoid cells drive interleukin-23-dependent innate intestinal pathology," Nature, vol. 464, no. 7293, pp. 1371-1375, 2010.

[21] A. C. Liu, M. Lee, B. M. McManus, and J. C. Choy, "Induction of endothelial nitric oxide synthase expression by IL-17 in human vascular endothelial cells: implications for vascular remodeling in transplant vasculopathy," Journal of Immunology, vol. 188, no. 3, pp. 1544-1550, 2012.
[22] A. Hot, V. Lenief, and P. Miossec, "Combination of IL-17 and $\mathrm{TNF} \alpha$ induces a pro-inflammatory, pro-coagulant and prothrombotic phenotype in human endothelial cells," Annals of the Rheumatic Diseases, vol. 71, no. 5, pp. 768-776, 2012.

[23] C.-Y. Kao, Y. Chen, P. Thai et al., "IL-17 markedly up-regulates $\beta$ defensin-2 expression in human airway epithelium via JAK and NF- $\kappa$ B signaling pathways," Journal of Immunology, vol. 173, no. 5, pp. 3482-3491, 2004.

[24] F. Huang, C.-Y. Kao, S. Wachi, P. Thai, J. Ryu, and R. Wu, "Requirement for both JAK-mediated PI3K signaling and ACT1/TRAF6/TAK1-dependent NF- $\kappa$ B activation by IL-17A in enhancing cytokine expression in human airway epithelial cells," Journal of Immunology, vol. 179, no. 10, pp. 6504-6513, 2007.

[25] T. Fujisawa, S. Velichko, P. Thai, L.-Y. Hung, F. Huang, and R. $\mathrm{Wu}$, "Regulation of airway MUC5AC expression by IL- $1 \beta$ and IL-17A; the NF- $\kappa$ B paradigm," Journal of Immunology, vol. 183, no. 10, pp. 6236-6243, 2009.

[26] S. Molet, Q. Hamid, F. Davoine et al., "IL-17 is increased in asthmatic airways and induces human bronchial fibroblasts to produce cytokines," Journal of Allergy and Clinical Immunology, vol. 108, no. 3, pp. 430-438, 2001.

[27] S.-Y. Hwang, J.-Y. Kim, K.-W. Kim et al., "IL-17 induces production of IL- 6 and IL-8 in rheumatoid arthritis synovial fibroblasts via NF-kappaB- and PI3-kinase/Akt-dependent pathways," Arthritis Research \& Therapy, vol. 6, no. 2, pp. R120-128, 2004.

[28] D. Toy, D. Kugler, M. Wolfson et al., "Cutting edge: interleukin 17 signals through a heteromeric receptor complex," Journal of Immunology, vol. 177, no. 1, pp. 36-39, 2006.

[29] A. W. Ho and S. L. Gaffen, "IL-17RC: a partner in IL-17 signaling and beyond," Seminars in Immunopathology, vol. 32, no. 1, pp. 33-42, 2010.

[30] H. H. Hofstetter, S. M. Ibrahim, D. Koczan et al., "Therapeutic efficacy of IL-17 neutralization in murine experimental autoimmune encephalomyelitis," Cellular Immunology, vol. 237, no. 2, pp. 123-130, 2005.

[31] M. Chabaud, P. Garnero, J.-M. Dayer, P.-A. Guerne, F. Fossiez, and P. Miossec, "Contribution of interleukin 17 to synovium matrix destruction in rheumatoid arthritis," Cytokine, vol. 12, no. 7, pp. 1092-1099, 2000.

[32] Y. Hu, F. Shen, N. K. Crellin, and W. Ouyang, "The IL-17 pathway as a major therapeutic target in autoimmune diseases," Annals of the New York Academy of Sciences, vol. 1217, no. 1, pp. 60-76, 2011.

[33] S. Sergejeva, S. Ivanov, J. Lötvall, and A. Lindén, "Interleukin-17 as a recruitment and survival factor for airway macrophages in allergic airway inflammation," American Journal of Respiratory Cell and Molecular Biology, vol. 33, no. 3, pp. 248-253, 2005.

[34] M. Laan, L. Palmberg, K. Larsson, and A. Lindén, "Free, soluble interleukin-17 protein during severe inflammation in human airways," European Respiratory Journal, vol. 19, no. 3, pp. 534537, 2002.

[35] R. He, M. K. Oyoshi, H. Jin, and R. S. Geha, "Epicutaneous antigen exposure induces a Th17 response that drives airway inflammation after inhalation challenge," Proceedings of the National Academy of Sciences of the United States of America, vol. 104, no. 40, pp. 15817-15822, 2007.

[36] M. Brodlie, M. C. McKean, G. E. Johnson et al., "Raised interleukin-17 is immunolocalised to neutrophils in cystic fibrosis lung disease," European Respiratory Journal, vol. 37, no. 6, pp. 1378-1385, 2011. 
[37] H.-L. Tan, N. Regamey, S. Brown, A. Bush, C. M. Lloyd, and J. C. Davies, "The Th17 pathway in cystic fibrosis lung disease," American Journal of Respiratory and Critical Care Medicine, vol. 184, no. 2, pp. 252-258, 2011.

[38] M. A. Kleinschek, K. Boniface, S. Sadekova et al., "Circulating and gut-resident human Th17 cells express CD161 and promote intestinal inflammation," Journal of Experimental Medicine, vol. 206, no. 3, pp. 525-534, 2009.

[39] T. Kobayashi, S. Okamoto, T. Hisamatsu et al., "IL23 differentially regulates the Th1/Th17 balance in ulcerative colitis and Crohn's disease," Gut, vol. 57, no. 12, pp. 1682-1689, 2008.

[40] F. McAllister, A. Henry, J. L. Kreindler et al., "Role of IL$17 \mathrm{~A}, \mathrm{IL}-17 \mathrm{~F}$, and the IL-17 receptor in regulating growthrelated oncogene- $\alpha$ and granulocyte colony-stimulating factor in bronchial epithelium: implications for airway inflammation in cystic fibrosis," Journal of Immunology, vol. 175, no. 1, pp. 404412, 2005.

[41] L. E. Harrington, R. D. Hatton, P. R. Mangan et al., "Interleukin 17-producing $\mathrm{CD} 4^{+}$effector T cells develop via a lineage distinct from the T helper type 1 and 2 lineages," Nature Immunology, vol. 6, no. 11, pp. 1123-1132, 2005.

[42] H. Park, Z. Li, X. O. Yang et al., "A distinct lineage of CD4 T cells regulates tissue inflammation by producing interleukin 17," Nature Immunology, vol. 6, no. 11, pp. 1133-1141, 2005.

[43] E. Bettelli, Y. Carrier, W. Gao et al., "Reciprocal developmental pathways for the generation of pathogenic effector TH17 and regulatory T cells," Nature, vol. 441, no. 7090, pp. 235-238, 2006.

[44] P. R. Mangan, L. E. Harrington, D. B. O'Quinn et al., “Transforming growth factor- $\beta$ induces development of the T H17 lineage," Nature, vol. 441, no. 7090, pp. 231-234, 2006.

[45] X. O. Yang, A. D. Panopoulos, R. Nurieva et al., "STAT3 regulates cytokine-mediated generation of inflammatory helper T cells," Journal of Biological Chemistry, vol. 282, no. 13, pp. 9358-9363, 2007.

[46] T. Korn, E. Bettelli, W. Gao et al., "IL-21 initiates an alternative pathway to induce proinflammatory T H17 cells," Nature, vol. 448, no. 7152, pp. 484-487, 2007.

[47] L. Wei, A. Laurence, K. M. Elias, and J. J. O'Shea, "IL-21 is produced by Th17 cells and drives IL-17 production in a STAT3dependent manner," Journal of Biological Chemistry, vol. 282, no. 48, pp. 34605-34610, 2007.

[48] Y. Chung, S. H. Chang, G. J. Martinez et al., "Critical regulation of early Th17 cell differentiation by interleukin-1 signaling," Immunity, vol. 30, no. 4, pp. 576-587, 2009.

[49] E. de Jong, T. Suddason, and G. M. Lord, "Translational minireview series on Th17 Cells: development of mouse and human T helper 17 cells," Clinical and Experimental Immunology, vol. 159, no. 2, pp. 148-158, 2010.

[50] L. Cosmi, R. De Palma, V. Santarlasci et al., "Human interleukin 17-producing cells originate from a CD161 ${ }^{+} \mathrm{CD} 4^{+} \mathrm{T}$ cell precursor," Journal of Experimental Medicine, vol. 205, no. 8, pp. 19031916, 2008.

[51] E. V. Acosta-Rodriguez, G. Napolitani, A. Lanzavecchia, and F. Sallusto, "Interleukins $1 \beta$ and 6 but not transforming growth factor- $\beta$ are essential for the differentiation of interleukin 17producing human T helper cells," Nature Immunology, vol. 8, no. 9, pp. 942-949, 2007.

[52] E. Volpe, N. Servant, R. Zollinger et al., "A critical function for transforming growth factor- $\beta$, interleukin 23 and proinflammatory cytokines in driving and modulating human TH-17 responses," Nature Immunology, vol. 9, no. 6, pp. 650-657, 2008.
[53] V. Santarlasci, L. Maggi, M. Capone et al., "TGF- $\beta$ indirectly favors the development of human Th17 cells by inhibiting Th1 cells," European Journal of Immunology, vol. 39, no. 1, pp. 207215, 2009.

[54] N. Manel, D. Unutmaz, and D. R. Littman, "The differentiation of human TH-17 cells requires transforming growth factor- $\beta$ and induction of the nuclear receptor ROR $\gamma \mathrm{t}$," Nature Immunology, vol. 9, no. 6, pp. 641-649, 2008.

[55] L. Zhou, J. E. Lopes, M. M. W. Chong et al., “TGF-B-induced Foxp3 inhibits TH17 cell differentiation by antagonizing ROR $\gamma \mathrm{t}$ function," Nature, vol. 453, no. 7192, pp. 236-240, 2008.

[56] E. S. Hwang, "Transcriptional regulation of T helper 17 cell differentiation," Yonsei Medical Journal, vol. 51, no. 4, pp. 484491, 2010.

[57] V. Lazarevic, X. Chen, J.-H. Shim et al., “T-bet represses TH 17 differentiation by preventing Runxl-mediated activation of the gene encoding ROR $\gamma \mathrm{t}$," Nature Immunology, vol. 12, no. 1, pp. 96-104, 2011.

[58] B. U. Schraml, K. Hildner, W. Ise et al., "The AP-1 transcription factor Batf controls T H 17 differentiation," Nature, vol. 460, no. 7253, pp. 405-409, 2009.

[59] I. I. Ivanov, B. S. McKenzie, L. Zhou et al., "The orphan nuclear receptor ROR $\gamma$ t directs the differentiation program of proinflammatory IL-17 ${ }^{+}$T helper cells," Cell, vol. 126, no. 6, pp. 1121-1133, 2006.

[60] K. Ichiyama, H. Yoshida, Y. Wakabayashi et al., "Foxp3 inhibits ROR $\gamma$ t-mediated IL-17A mRNA transcription through direct interaction with ROR $\gamma \mathrm{t}$," Journal of Biological Chemistry, vol. 283, no. 25, pp. 17003-17008, 2008.

[61] M. Veldhoen, K. Hirota, J. Christensen, A. O'Garra, and B. Stockinger, "Natural agonists for aryl hydrocarbon receptor in culture medium are essential for optimal differentiation of Th17 T cells," Journal of Experimental Medicine, vol. 206, no. 1, pp. 43-49, 2009.

[62] A. Brüstle, S. Heink, M. Huber et al., "The development of inflammatory TH-17 cells requires interferon-regulatory factor 4," Nature Immunology, vol. 8, no. 9, pp. 958-966, 2007.

[63] M. Huber, A. Brüstle, K. Reinhard et al., "IRF4 is essential for IL-21-mediated induction, amplification, and stabilization of the Th17 phenotype," Proceedings of the National Academy of Sciences of the United States of America, vol. 105, no. 52, pp. 20846-20851, 2008.

[64] A.-N. N. Ahyi, H.-C. Chang, A. L. Dent, S. L. Nutt, and M. H. Kaplan, "IFN regulatory factor 4 regulates the expression of a subset of Th2 cytokines," Journal of Immunology, vol. 183, no. 3, pp. 1598-1606, 2009.

[65] C. Neufert, C. Becker, S. Wirtz et al., "IL-27 controls the development of inducible regulatory $\mathrm{T}$ cells and Th17 cells via differential effects on STAT1," European Journal of Immunology, vol. 37, no. 7, pp. 1809-1816, 2007.

[66] C. Diveu, M. J. McGeachy, K. Boniface et al., "IL-27 blocks RORc expression to inhibit lineage commitment of Th17 cells," Journal of Immunology, vol. 182, no. 9, pp. 5748-5756, 2009.

[67] A. Laurence, C. M. Tato, T. S. Davidson et al., "Interleukin2 signaling via STAT5 constrains T helper 17 cell generation," Immunity, vol. 26, no. 3, pp. 371-381, 2007.

[68] X.-P. Yang, K. Ghoreschi, S. M. Steward-Tharp et al., "Opposing regulation of the locus encoding IL-17 through direct, reciprocal actions of STAT3 and STAT5," Nature Immunology, vol. 12, no. 3, pp. 247-254, 2011. 
[69] T. Korn, E. Bettelli, M. Oukka, and V. K. Kuchroo, "IL-17 and Th17 cells," Annual Review of Immunology, vol. 27, pp. 485-517, 2009.

[70] Y. Zheng, P. A. Valdez, D. M. Danilenko et al., "Interleukin22 mediates early host defense against attaching and effacing bacterial pathogens," Nature Medicine, vol. 14, no. 3, pp. 282289, 2008.

[71] L. A. Solt, T. M. Kamenecka, and T. P. Burris, "LXR-mediated inhibition of $\mathrm{CD}^{+} \mathrm{T}$ helper cells," PLoS ONE, vol. 7, no. 9, Article ID e46615, 2012.

[72] L. A. Solt, N. Kumar, P. Nuhant et al., "Suppression of TH 17 differentiation and autoimmunity by a synthetic ROR ligand," Nature, vol. 472, no. 7344, pp. 491-494, 2011.

[73] Z. Yao, S. L. Painter, W. C. Fanslow et al., "Human IL-17: a novel cytokine derived from T cells," Journal of Immunology, vol. 155, no. 12, pp. 5483-5486, 1995.

[74] E. Rouvier, M.-F. Luciani, M.-G. Mattei, F. Denizot, and P. Golstein, "CTLA-8, cloned from an activated T cell, bearing AUrich messenger RNA instability sequences, and homologous to a herpesvirus Saimiri gene," Journal of Immunology, vol. 150, no. 12, pp. 5445-5456, 1993.

[75] S. Aggarwal and A. L. Gurney, "IL-17: prototype member of an emerging cytokine family," Journal of Leukocyte Biology, vol. 71, no. 1, pp. 1-8, 2002.

[76] J. M. Reynolds, P. Angkasekwinai, and C. Dong, "IL-17 family member cytokines: regulation and function in innate immunity," Cytokine and Growth Factor Reviews, vol. 21, no. 6, pp. 413-423, 2010.

[77] R. E. Kuestner, D. W. Taft, A. Haran et al., "Identification of the IL-17 receptor related molecule IL-17RC as the receptor for IL17F," Journal of Immunology, vol. 179, no. 8, pp. 5462-5473, 2007.

[78] J. M. Kramer, L. Yi, F. Shen et al., "Cutting edge: evidence for ligand-independent multimerization of the IL-17 receptor," Journal of Immunology, vol. 176, no. 2, pp. 711-715, 2006.

[79] J. M. Kramer, W. Hanel, F. Shen et al., "Cutting edge: identification of a pre-ligand assembly domain (PLAD) and ligand binding site in the IL-17 receptor," Journal of Immunology, vol. 179, no. 10, pp. 6379-6383, 2007.

[80] F. Shen and S. L. Gaffen, "Structure-function relationships in the IL-17 receptor: implications for signal transduction and therapy," Cytokine, vol. 41, no. 2, pp. 92-104, 2008.

[81] S. Zrioual, M.-L. Toh, A. Tournadre et al., "IL-17RA and IL17RC receptors are essential for IL-17A-induced $\mathrm{ELR}^{+}$CXC chemokine expression in synoviocytes and are overexpressed in rheumatoid blood 1," Journal of Immunology, vol. 180, no. 1, pp. 655-663, 2008.

[82] J. Lee, W.-H. Ho, M. Maruoka et al., "IL-17E, a novel proinflammatory ligand for the IL-17 receptor homolog IL-17Rh1," Journal of Biological Chemistry, vol. 276, no. 2, pp. 1660-1664, 2001.

[83] Y. Yamaguchi, K. Fujio, H. Shoda et al., "IL-17B and IL-17C are associated with TNF- $\alpha$ production and contribute to the exacerbation of inflammatory arthritis," Journal of Immunology, vol. 179, no. 10, pp. 7128-7136, 2007.

[84] S. H. Chang, J. M. Reynolds, B. P. Pappu, G. Chen, G. J. Martinez, and C. Dong, "Interleukin-17C promotes Th17 cell responses and autoimmune disease via interleukin-17 receptor E," Immunity, vol. 35, no. 4, pp. 611-621, 2011.

[85] V. Ramirez-Carrozzi, A. Sambandam, E. Luis et al., "IL-17C regulates the innate immune function of epithelial cells in an autocrine manner," Nature Immunology, vol. 12, no. 12, pp. 11591166, 2011.
[86] X. Song, S. Zhu, P. Shi et al., "IL-17RE is the functional receptor for IL-17C and mediates mucosal immunity to infection with intestinal pathogens," Nature Immunology, vol. 12, no. 12, pp. 1151-1158, 2011.

[87] T. Starnes, H. E. Broxmeyer, M. J. Robertson, and R. Hromas, "Cutting edge: IL-17D, a novel member of the IL-17 family, stimulates cytokine production and inhibits hemopoiesis," Journal of Immunology, vol. 169, no. 2, pp. 642-646, 2002.

[88] S. L. Gaffen, "Structure and signalling in the IL-17 receptor family," Nature Reviews Immunology, vol. 9, no. 8, pp. 556-567, 2009.

[89] L. K. Ely, S. Fischer, and K. C. Garcia, "Structural basis of receptor sharing by interleukin 17 cytokines," Nature Immunology, vol. 10, no. 12, pp. 1245-1251, 2009.

[90] M. Novatchkova, A. Leibbrandt, J. Werzowa, A. Neubüser, and F. Eisenhaber, "The STIR-domain superfamily in signal transduction, development and immunity," Trends in Biochemical Sciences, vol. 28, no. 5, pp. 226-229, 2003.

[91] A. Mansell, E. Brint, J. A. Gould, L. A. O’Neill, and P. J. Hertzog, "Mal interacts with tumor necrosis factor receptorassociated factor (TRAF)- 6 to mediate NF- $\kappa$ B activation by Toll-like receptor (TLR)-2 and TLR4," Journal of Biological Chemistry, vol. 279, no. 36, pp. 37227-37230, 2004.

[92] L. A. J. O'Neill and A. G. Bowie, "The family of five: TIRdomain-containing adaptors in Toll-like receptor signalling," Nature Reviews Immunology, vol. 7, no. 5, pp. 353-364, 2007.

[93] V. Y. Toshchakov and S. N. Vogel, "Cell-penetrating TIR BB loop decoy peptides: a novel class of TLR signaling inhibitors and a tool to study topology of TIR-TIR interactions," Expert Opinion on Biological Therapy, vol. 7, no. 7, pp. 1035-1050, 2007.

[94] A. Maitra, F. Shen, W. Hanel et al., "Distinct functional motifs within the IL-17 receptor regulate signal transduction and target gene expression," Proceedings of the National Academy of Sciences of the United States of America, vol. 104, no. 18, pp. 7506-7511, 2007.

[95] F. Shen, N. Li, P. Gade et al., "IL-17 receptor signaling inhibits $\mathrm{C} / \mathrm{EBPb}$ by sequential phosphorylation of the regulatory 2 domain," Science Signaling, vol. 2, no. 59, p. ra8, 2009.

[96] S. Swaidani, K. Bulek, Z. Kang et al., "The critical role of epithelial-derived Act1 in IL-17- and IL-25-mediated pulmonary inflammation," Journal of Immunology, vol. 182, no. 3, pp. 16311640,2009

[97] S. H. Chang, H. Park, and C. Dong, "Actl adaptor protein is an immediate and essential signaling component of interleukin-17 receptor," Journal of Biological Chemistry, vol. 281, no. 47, pp. 35603-35607, 2006.

[98] Y. Qian, C. Liu, J. Hartupee et al., "The adaptor Actl is required for interleukin 17 -dependent signaling associated with autoimmune and inflammatory disease," Nature Immunology, vol. 8, no. 3, pp. 247-256, 2007.

[99] C. Liu, S. Swaidani, W. Qian et al., “A CC' loop decoy peptide blocks the interaction between Act1 and IL-17RA to attenuate IL-17- and IL-25-induced inflammation," Science Signaling, vol. 4, no. 197, article ra72, 2011.

[100] A. W. Ho, F. Shen, H. R. Conti et al., "IL-17RC is required for immune signaling via an extended SEF/IL-17R signaling domain in the cytoplasmic tail," Journal of Immunology, vol. 185, no. 2, pp. 1063-1070, 2010.

[101] R. Schwandner, K. Yamaguchi, and Z. Cao, "Requirement of tumor necrosis factor receptor-associated factor (TRAF)6 in interleukin 17 signal transduction," Journal of Experimental Medicine, vol. 191, no. 7, pp. 1233-1239, 2000. 
[102] S. Zhu, W. Pan, P. Shi et al., "Modulation of experimental autoimmune encephalomyelitis through TRAF3-mediated suppression of interleukin 17 receptor signaling," Journal of Experimental Medicine, vol. 207, no. 12, pp. 2647-2662, 2010.

[103] C. Liu, W. Qian, Y. Qian et al., "Act1, a U-box E3 ubiquitin ligase for IL-17 signaling," Science Signaling, vol. 2, no. 92, p. ra63, 2009.

[104] S. U. Sønder, S. Saret, W. Tang, D. E. Sturdevant, S. F. Porcella, and U. Siebenlist, "IL-17-induced NF- $\kappa$ B activation via CIKS/Actl physiologic significance and signaling mechanisms," Journal of Biological Chemistry, vol. 286, no. 15, pp. 12881-12890, 2011.

[105] C.-Y. Kao, C. Kim, F. Huang, and R. Wu, "Requirements for two proximal NF- $\kappa \mathrm{B}$ binding sites and $\mathrm{I} \kappa \mathrm{B}-\zeta$ in IL-17Ainduced human $\beta$-defensin 2 expression by conducting airway epithelium," Journal of Biological Chemistry, vol. 283, no. 22, pp. 15309-15318, 2008.

[106] Y. Zhou, M.-L. Toh, S. Zrioual, and P. Miossec, "IL-17A versus IL-17F induced intracellular signal transduction pathways and modulation by IL-17RA and IL-17RC RNA interference in AGS gastric adenocarcinoma cells," Cytokine, vol. 38, no. 3, pp. 157164, 2007.

[107] A. Hot, S. Zrioual, M.-L. Toh, V. Lenief, and P. Miossec, "IL17A- versus IL-17F-induced intracellular signal transduction pathways and modulation by IL-17RA and IL-17RC RNA interference in rheumatoid synoviocytes," Annals of the Rheumatic Diseases, vol. 70, no. 2, pp. 341-348, 2011.

[108] Y. Chen, P. Thai, Y.-H. Zhao, Y.-S. Ho, M. M. DeSouza, and $\mathrm{R}$. Wu, "Stimulation of airway mucin gene expression by interleukin (IL)-17 through IL-6 paracrine/autocrine loop," Journal of Biological Chemistry, vol. 278, no. 19, pp. 17036-17043, 2003.

[109] C.-Y. Kao, F. Huang, Y. Chen et al., "Up-regulation of CC chemokine ligand 20 expression in human airway epithelium by IL-17 through a JAK-independent but MEK/NF- $\kappa$ B-dependent signaling pathway," Journal of Immunology, vol. 175, no. 10, pp. 6676-6685, 2005.

[110] F. Huang, S. Wachi, P. Thai et al., "Potentiation of IL-19 expression in airway epithelia by IL-17A and IL-4/IL-13: important implications in asthma," Journal of Allergy and Clinical Immunology, vol. 121, no. 6, pp. 1415-1421, 2008.

[111] M. Laan, J. Lotvall, K. F. Chung, and A. Linden, "IL-17-induced cytokine release in human bronchial epithelial cells in vitro: role of mitogen-activated protein (MAP) kinases," British Journal of Pharmacology, vol. 133, no. 1, pp. 200-206, 2001.

[112] O. Prause, M. Laan, J. Lötvall, and A. Lindén, "Pharmacological modulation of interleukin-17-induced GCP-2-, GRO- $\alpha$ and interleukin-8 release in human bronchial epithelial cells," European Journal of Pharmacology, vol. 462, no. 1-3, pp. 193198, 2003.

[113] J. Hartupee, C. Liu, M. Novotny, X. Li, and T. Hamilton, "IL-17 enhances chemokine gene expression through mRNA stabilization," Journal of Immunology, vol. 179, no. 6, pp. 41354141, 2007.

[114] J. Hartupee, C. Liu, M. Novotny, D. Sun, X. Li, and T. A. Hamilton, "IL-17 signaling for mRNA stabilization does not require TNF receptor-associated factor 6," Journal of Immunology, vol. 182, no. 3, pp. 1660-1666, 2009.

[115] S. Datta, M. Novotny, P. G. Pavicic Jr. et al., "IL-17 regulates CXCL1 mRNA stability via an AUUUA/tristetraprolinindependent sequence," Journal of Immunology, vol. 184, no. 3, pp. 1484-1491, 2010.
[116] R. M. Onishi, S. J. Park, W. Hanel, A. W. Ho, A. Maitra, and S. L. Gaffen, "SEF/IL-17R (SEFIR) is not enough: an extended SEFIR domain is required for IL-17RA-mediated signal transduction," Journal of Biological Chemistry, vol. 285, no. 43, pp. 32751-32759, 2010.

[117] K. Bulek, C. Liu, S. Swaidani et al., "The inducible kinase IKKi is required for IL-17-dependent signaling associated with neutrophilia and pulmonary inflammation," Nature Immunology, vol. 12, no. 9, pp. 844-852, 2011.

[118] F. Qu, H. Gao, S. Zhu et al., "TRAF6-dependent Actl phosphorylation by the IkappaB kinase-related kinases suppresses interleukin-17-induced NF-kappaB activation," Molecular and Cellular Biology, vol. 32, no. 19, pp. 3925-3937, 2012.

[119] D. Haudenschild, T. Moseley, L. Rose, and A. Hari Reddi, "Soluble and transmembrane isoforms of novel interleukin17 receptor-like protein by RNA splicing and expression in prostate cancer," Journal of Biological Chemistry, vol. 277, no. 6, pp. 4309-4316, 2002.

[120] H. Ishigame, S. Kakuta, T. Nagai et al., "Differential roles of interleukin-17 A and -17F in host defense against mucoepithelial bacterial infection and allergic responses," Immunity, vol. 30, no. 1, pp. 108-119, 2009.

[121] E. Silverpil, A. K. Wright, M. Hansson et al., "Negative feedback on IL-23 exerted byIL-17A during pulmonary inflammation," Innate Immunity. In press.

[122] M. Ziolkowska, A. Koc, G. Luszczykiewicz et al., "High levels of IL-17 in rheumatoid arthritis patients: IL-15 triggers in vitro IL17 production via cyclosporin A-sensitive mechanism," Journal of Immunology, vol. 164, no. 5, pp. 2832-2838, 2000.

[123] M. Chabaud, J. M. Durand, N. Buchs et al., "Human interleukin17: a T cell-derived proinflammatory cytokine produced by the rheumatoid synovium," Arthritis \& Rheumatism, vol. 42, no. 5, pp. 963-970, 1999.

[124] S.-Y. Hwang and H.-Y. Kim, "Expression of IL-17 homologs and their receptors in the synovial cells of rheumatoid arthritis patients," Molecules and Cells, vol. 19, no. 2, pp. 180-184, 2005.

[125] F. Zhang, C.-L. Wang, Y. Koyama et al., "Compressive force stimulates the gene expression of IL-17s and their receptors in MC3T3-E1 cells," Connective Tissue Research, vol. 51, no. 5, pp. 359-369, 2010.

[126] Z. Rong, A. Wang, Z. Li et al., "IL-17RD (Sef or IL-17RLM) interacts with IL-17 receptor and mediates IL-17 signaling," Cell Research, vol. 19, no. 2, pp. 208-215, 2009.

[127] M. Mellett, P. Atzei, A. Horgan et al., "Orphan receptor IL-17RD tunes IL-17A signalling and is required for neutrophilia," Nature Communications, vol. 3, p. 1119, 2012.

[128] R. M. Onishi and S. L. Gaffen, "Interleukin-17 and its target genes: mechanisms of interleukin-17 function in disease," Immunology, vol. 129, no. 3, pp. 311-321, 2010.

[129] A. Doreau, A. Belot, J. Bastid et al., "Interleukin 17 acts in synergy with B cell-activating factor to influence B cell biology and the pathophysiology of systemic lupus erythematosus," Nature Immunology, vol. 10, no. 7, pp. 778-785, 2009.

[130] D. V. Jovanovic, J. A. Di Battista, J. Martel-Pelletier et al., "Modulation of TIMP-1 synthesis by antiinflammatory cytokines and prostaglandin E2 in interleukin 17 stimulated human monocytes/macrophages," Journal of Rheumatology, vol. 28, no. 4, pp. 712-718, 2001.

[131] D. V. Jovanovic, J. Martel-Pelletier, J. A. Di Battista et al., "Stimulation of 92-kd gelatinase (matrix metalloproteinase 9) production by interleukin-17 in human monocyte/macrophages: a 
possible role in rheumatoid arthritis," Arthritis \& Rheumatism, vol. 43, no. 5, pp. 1134-1144, 2000.

[132] M. Laan, O. Prause, M. Miyamoto et al., "A role of GM-CSF in the accumulation of neutrophils in the airways caused by IL17 and TNF- $\alpha$," European Respiratory Journal, vol. 21, no. 3, pp. 387-393, 2003.

[133] P. Ye, F. H. Rodriguez, S. Kanaly et al., "Requirement of interleukin 17 receptor signaling for lung CXC chemokine and granulocyte colony-stimulating factor expression, neutrophil recruitment, and host defense," Journal of Experimental Medicine, vol. 194, no. 4, pp. 519-527, 2001.

[134] A. Lindén, M. Laan, and G. P. Anderson, "Neutrophils, interleukin-17A and lung disease," European Respiratory Journal, vol. 25, no. 1, pp. 159-172, 2005.

[135] S. P. Singh, H. H. Zhang, J. F. Foley, M. N. Hedrick, and J. M. Farber, "Human T cells that are able to produce IL-17 express the chemokine receptor CCR6," Journal of Immunology, vol. 180, no. 1, pp. 214-221, 2008.

[136] S.-C. Liao, Y.-C. Cheng, Y.-C. Wang et al., "IL-19 induced Th2 cytokines and was up-regulated in asthma patients," Journal of Immunology, vol. 173, no. 11, pp. 6712-6718, 2004.

[137] K. M. Scanlon, R. J. Hawksworth, S. J. Lane, and B. P. Mahon, "IL-17A induces CCL28, supporting the chemotaxis of IgEsecreting B cells," International Archives of Allergy and Immunology, vol. 156, no. 1, pp. 51-61, 2011.

[138] D. Inoue, M. Numasaki, M. Watanabe et al., "IL-17A promotes the growth of airway epithelial cells through ERK-dependent signaling pathway," Biochemical and Biophysical Research Communications, vol. 347, no. 4, pp. 852-858, 2006.

[139] M. Kawaguchi, F. Kokubu, H. Kuga et al., "Modulation of bronchial epithelial cells by IL-17," Journal of Allergy and Clinical Immunology, vol. 108, no. 5, pp. 804-809, 2001.

[140] T. Kinugasa, T. Sakaguchi, X. Gu, and H. Reinecker, "Claudins regulate the intestinal barrier in response to immune mediators," Gastroenterology, vol. 118, no. 6, pp. 1001-1011, 2000.

[141] M. Kudo, A. C. Melton, C. Chen et al., "IL-17A produced by $\alpha \beta$ T cells drives airway hyper-responsiveness in mice and enhances mouse and human airway smooth muscle contraction," Nature Medicine, vol. 18, no. 4, pp. 547-554, 2012.

[142] M. Numasaki, Y. Tomioka, H. Takahashi, and H. Sasaki, "IL-17 and IL-17F modulate GM-CSF production by lung microvascular endothelial cells stimulated with IL- $\beta$ and/or TNF- $\alpha$," Immunology Letters, vol. 95, no. 2, pp. 175-184, 2004.

[143] M. Numasaki, H. Takahashi, Y. Tomioka, and H. Sasaki, "Regulatory roles of IL-17 and IL-17F in G-CSF production by lung microvascular endothelial cells stimulated with IL-1 $\beta$ and/or TNF- $\alpha$," Immunology Letters, vol. 95, no. 1, pp. 97-104, 2004.

[144] H. Fujie, K. Niu, M. Ohba et al., "A distinct regulatory role of Th17 cytokines IL-17A and IL-17F in chemokine secretion from lung microvascular endothelial cells," Inflammation, vol. 35, no. 3, pp. 1119-1131, 2012.

[145] C. E. Jones and K. Chan, "Interleukin-17 stimulates the expression of interleukin-8, growth-related oncogene- $\alpha$, and granulocyte-colony-stimulating factor by human airway epithelial cells," American Journal of Respiratory Cell and Molecular Biology, vol. 26, no. 6, pp. 748-753, 2002.

[146] E. M. Moran, R. Mullan, J. McCormick et al., "Human rheumatoid arthritis tissue production of IL-17A drives matrix and cartilage degradation: synergy with tumour necrosis factor$\alpha$, Oncostatin M and response to biologic therapies," Arthritis Research and Therapy, vol. 11, no. 4, article R113, 2009.
[147] A. M. Woltman, S. De Haij, J. G. Boonstra, S. J. P. Gobin, M. R. Daha, and C. Van Kooten, "Interleukin-17 and CD40-Ligand synergistically enhance cytokine and chemokine production by renal epithelial cells," Journal of the American Society of Nephrology, vol. 11, no. 11, pp. 2044-2055, 2000.

[148] S. Mizunoe, T. Shuto, S. Suzuki et al., "and Toll-like receptor 2 and 4 signals to induce IL-8 expression in cystic fibrosis airway epithelial cells," Journal of Pharmacological Sciences, vol. 118, no. 4, pp. 512-520, 2012.

[149] X. Zhou, Q. Chen, J. Moore, J. K. Kolls, S. Halperin, and J. Wang, "Critical role of the interleukin-17/interleukin-17 receptor axis in regulating host susceptibility to respiratory infection with Chlamydia species," Infection and Immunity, vol. 77, no. 11, pp. 5059-5070, 2009.

[150] Q. Wu, R. J. Martin, J. G. Rino, R. Breed, R. M. Torres, and H. W. Chu, "IL-23-dependent IL-17 production is essential in neutrophil recruitment and activity in mouse lung defense against respiratory Mycoplasma pneumoniae infection," Microbes and Infection, vol. 9, no. 1, pp. 78-86, 2007.

[151] X. Zhang, L. Gao, L. Lei et al., "A MyD88-dependent early IL17 production protects mice against airway infection with the obligate intracellular pathogen Chlamydia muridarum," Journal of Immunology, vol. 183, no. 2, pp. 1291-1300, 2009.

[152] P. Ye, P. B. Garvey, P. Zhang et al., "Interleukin-17 and lung host defense against Klebsiella pneumoniae infection," American Journal of Respiratory Cell and Molecular Biology, vol. 25, no. 3, pp. 335-340, 2001.

[153] A. Kudva, E. V. Scheller, K. M. Robinson et al., "Influenza A inhibits Th17-mediated host defense against bacterial pneumonia in mice," Journal of Immunology, vol. 186, no. 3, pp. 16661674, 2011.

[154] W. Huang, L. Na, P. L. Fidel, and P. Schwarzenberger, "Requirement of interleukin-17A for systemic anti-Candida albicans host defense in mice," Journal of Infectious Diseases, vol. 190, no. 3, pp. 624-631, 2004.

[155] H. R. Conti, F. Shen, N. Nayyar et al., “Th17 cells and IL-17 receptor signaling are essential for mucosal host defense against oral candidiasis," Journal of Experimental Medicine, vol. 206, no. 2, pp. 299-311, 2009.

[156] Y. Miyazaki, S. Hamano, S. Wang, Y. Shimanoe, Y. Iwakura, and H. Yoshida, "IL-17 is necessary for host protection against acutephase Trypanosoma cruzi infection," Journal of Immunology, vol. 185, no. 2, pp. 1150-1157, 2010.

[157] C. E. Zielinski, F. Mele, D. Aschenbrenner et al., "Pathogeninduced human TH17 cells produce IFN- $\gamma$ or IL-10 and are regulated by IL-1 $\beta$," Nature, vol. 484, no. 7395, pp. 514-518, 2012.

[158] S. K. Datta, M. Sabet, K. P. L. Nguyen et al., "Mucosal adjuvant activity of cholera toxin requires Th17 cells and protects against inhalation anthrax," Proceedings of the National Academy of Sciences of the United States of America, vol. 107, no. 23, pp. 10638-10643, 2010.

[159] R. Gopal, J. Rangel-Moreno, S. Slight et al., "Interleukin-17dependent CXCL13 mediates mucosal vaccine-induced immunity against tuberculosis," Mucosal Immunology, 2013.

[160] M. Raffatellu, R. L. Santos, D. E. Verhoeven et al., "Simian immunodeficiency virus-induced mucosal interleukin-17 deficiency promotes Salmonella dissemination from the gut," Nature Medicine, vol. 14, no. 4, pp. 421-428, 2008.

[161] K. Wolf, G. V. Plano, and K. A. Fields, "A protein secreted by the respiratory pathogen Chlamydia pneumoniae impairs IL-17 signalling via interaction with human Actl," Cellular Microbiology, vol. 11, no. 5, pp. 769-779, 2009. 
[162] D. J. Cua and C. M. Tato, "Innate IL-17-producing cells: the sentinels of the immune system," Nature Reviews Immunology, vol. 10, no. 7, pp. 479-489, 2010.

[163] K. Hirota, H. Ahlfors, J. H. Duarte, and B. Stockinger, "Regulation and function of innate and adaptive interleukin-17producing cells," EMBO Reports, vol. 13, no. 2, pp. 113-120, 2012.

[164] C. E. Sutton, L. A. Mielke, and K. H. Mills, "IL-17-producing gammadelta $\mathrm{T}$ cells and innate lymphoid cells," European Journal of Immunology, vol. 42, no. 9, pp. 2221-2231, 2012.

[165] C. E. Sutton, S. J. Lalor, C. M. Sweeney, C. F. Brereton, E. C. Lavelle, and K. H. G. Mills, "Interleukin-1 and IL-23 induce innate IL-17 production from $\gamma \delta \mathrm{T}$ cells, amplifying Th17 responses and autoimmunity,' Immunity, vol. 31, no. 2, pp. 331341, 2009.

[166] N. Caccamo, C. La Mendola, V. Orlando et al., "Differentiation, phenotype, and function of interleukin-17-producing human v $\gamma 9 v \delta 2$ T cells," Blood, vol. 118, no. 1, pp. 129-138, 2011.

[167] S. J. Lalor, L. S. Dungan, C. E. Sutton, S. A. Basdeo, J. M. Fletcher, and K. H. G. Mills, "Caspase-1-processed cytokines IL-1 $\beta$ and IL-18 promote IL-17 production by $\gamma \delta$ and CD 4 T cells that mediate autoimmunity," Journal of Immunology, vol. 186, no. 10, pp. 5738-5748, 2011.

[168] M. Lochner, L. Peduto, M. Cherrier et al., "In vivo equilibrium of proinflammatory IL- $17^{+}$and regulatory IL- $10^{+}$Foxp $3^{+}$ROR $\gamma \mathrm{t}^{+}$ T cells," Journal of Experimental Medicine, vol. 205, no. 6, pp. 1381-1393, 2008.

[169] B. Martin, K. Hirota, D. J. Cua, B. Stockinger, and M. Veldhoen, "Interleukin-17-producing $\gamma \delta \mathrm{T}$ cells selectively expand in response to pathogen products and environmental signals," Immunity, vol. 31, no. 2, pp. 321-330, 2009.

[170] H. Spits, D. Artis, M. Colonna et al., "Innate lymphoid cells-a proposal for uniform nomenclature," Nature Reviews Immunology, vol. 13, no. 2, pp. 145-149, 2013.

[171] J. A. Walker, J. L. Barlow, and A. N. McKenzie, "Innate lymphoid cells-how did we miss them?" Nature Reviews Immunology, vol. 13, no. 2, pp. 75-87, 2013.

[172] N. Satoh-Takayama, C. A. J. Vosshenrich, S. Lesjean-Pottier et al., "Microbial flora drives interleukin 22 production in intestinal $\mathrm{NKp} 46^{+}$cells that provide innate mucosal immune defense," Immunity, vol. 29, no. 6, pp. 958-970, 2008.

[173] M. Cella, A. Fuchs, W. Vermi et al., "A human natural killer cell subset provides an innate source of IL-22 for mucosal immunity," Nature, vol. 457, no. 7230, pp. 722-725, 2009.

[174] A. V. Rachitskaya, A. M. Hansen, R. Horai et al., "Cutting edge: NKT cells constitutively express IL-23 receptor and ROR $\gamma \mathrm{t}$ and rapidly produce IL-17 upon receptor ligation in an IL-6independent fashion," Journal of Immunology, vol. 180, no. 8, pp. 5167-5171, 2008.

[175] M.-L. Michel, D. Mendes-da-Cruz, A. C. Keller et al., "Critical role of ROR- $\gamma \mathrm{t}$ in a new thymic pathway leading to IL-17producing invariant NKT cell differentiation," Proceedings of the National Academy of Sciences of the United States of America, vol. 105, no. 50, pp. 19845-19850, 2008.

[176] L. Campillo-Gimenez, M.-C. Cumont, M. Fay et al., "AIDS progression is associated with the emergence of IL-17-producing cells early after simian immunodeficiency virus infection," Journal of Immunology, vol. 184, no. 2, pp. 984-992, 2010.

[177] J.-M. Doisne, V. Soulard, C. Bécourt et al., "Cutting edge: crucial role of IL-1 and IL-23 in the innate IL-17 response of peripheral lymph node NK1.1- invariant NKT cells to bacteria," Journal of Immunology, vol. 186, no. 2, pp. 662-666, 2011.
[178] A. E. Price, R. L. Reinhardt, H. E. Liang, and R. M. Locksley, "Marking and quantifying IL-17A-producing cells in vivo," PLoS ONE, vol. 7, no. 6, Article ID e39750, 2012.

[179] M. Peng, Z. Wang, C. Yao et al., "Interleukin 17-producing $\gamma \delta \mathrm{T}$ cells increased in patients with active pulmonary tuberculosis," Cellular and Molecular Immunology, vol. 5, no. 3, pp. 203-208, 2008.

[180] Y. O. Yoshida, M. Umemura, A. Yahagi et al., "Essential role of IL-17A in the formation of a mycobacterial infection-induced granuloma in the lung," Journal of Immunology, vol. 184, no. 8, pp. 4414-4422, 2010.

[181] K. Kawakami, N. Yamamoto, Y. Kinjo et al., "Critical role of $\mathrm{V} \alpha 14^{+}$natural killer $\mathrm{T}$ cells in the innate phase of host protection against Streptococcus pneumoniae infection," European Journal of Immunology, vol. 33, no. 12, pp. 3322-3330, 2003.

[182] M. Umemura, A. Yahagi, S. Hamada et al., "IL-17-mediated regulation of innate and acquired immune response against pulmonary Mycobacterium bovis bacille Calmette-Guérin infection," Journal of Immunology, vol. 178, no. 6, pp. 3786-3796, 2007.

[183] S. A. Khader, G. K. Bell, J. E. Pearl et al., "IL-23 and IL-17 in the establishment of protective pulmonary $\mathrm{CD}^{+} \mathrm{T}$ cell responses after vaccination and during Mycobacterium tuberculosis challenge," Nature Immunology, vol. 8, no. 4, pp. 369-377, 2007. 


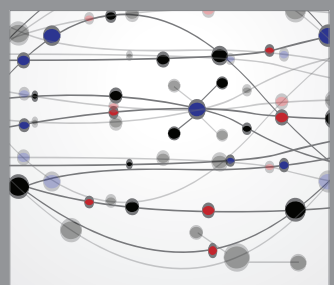

The Scientific World Journal
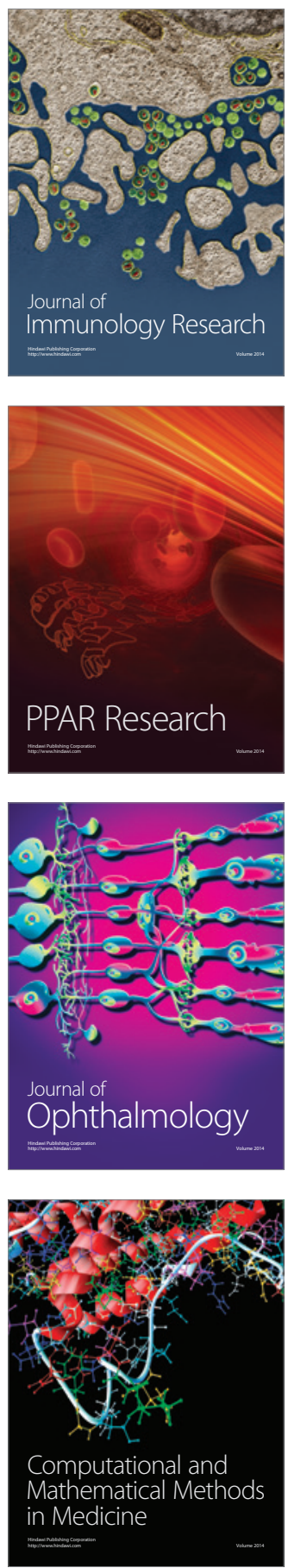

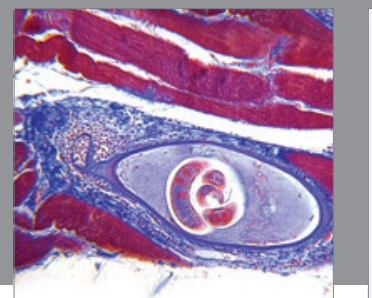

Gastroenterology

Research and Practice
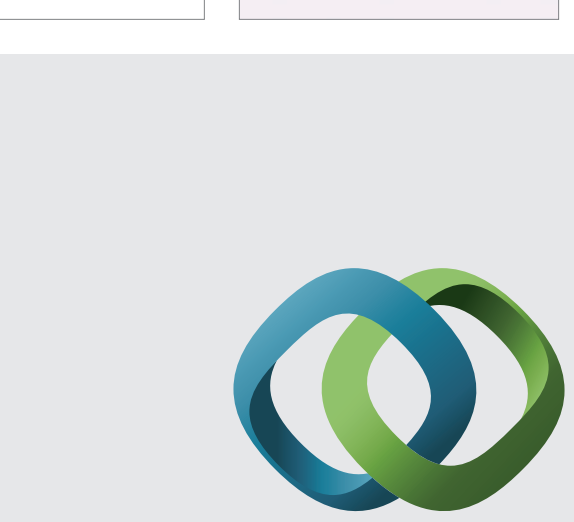

\section{Hindawi}

Submit your manuscripts at

http://www.hindawi.com
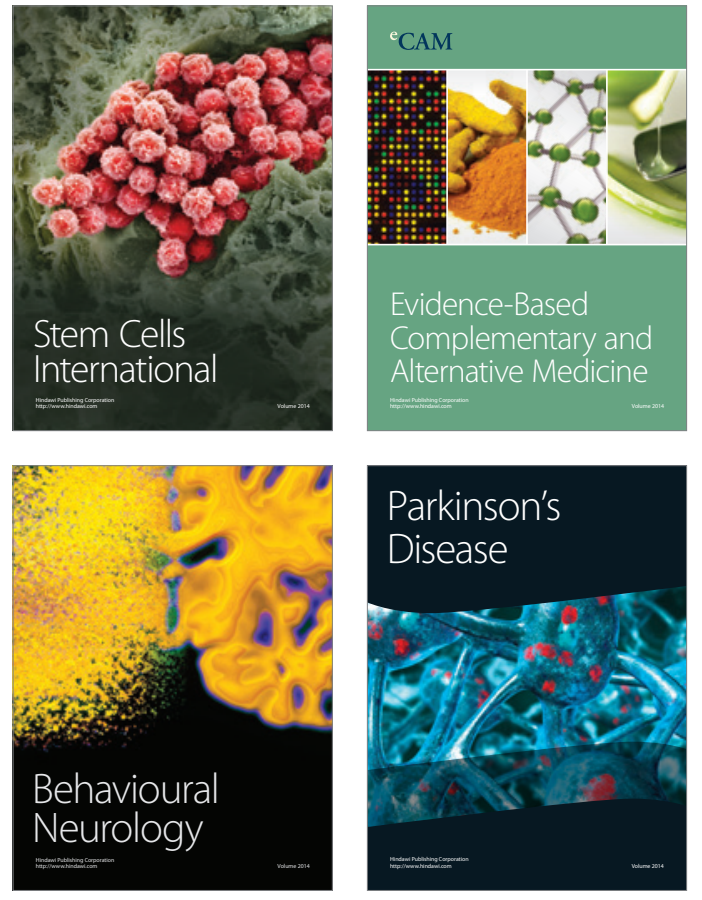
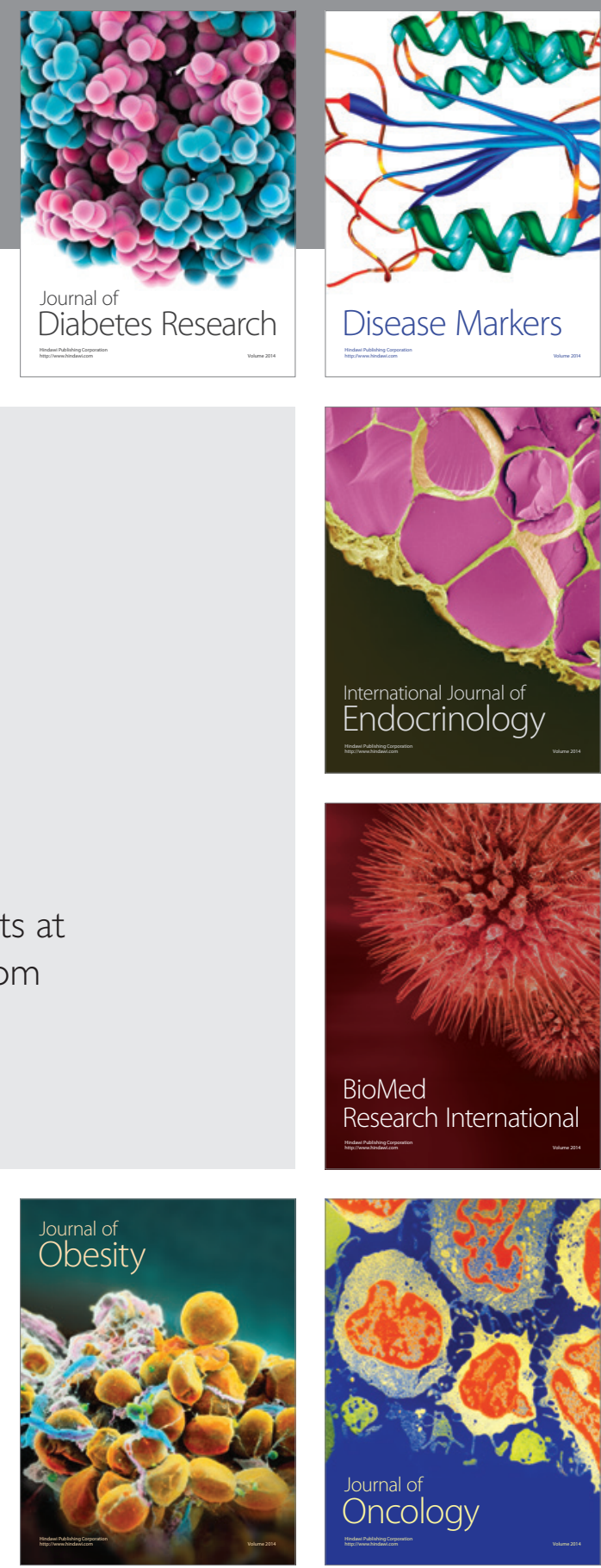

Disease Markers
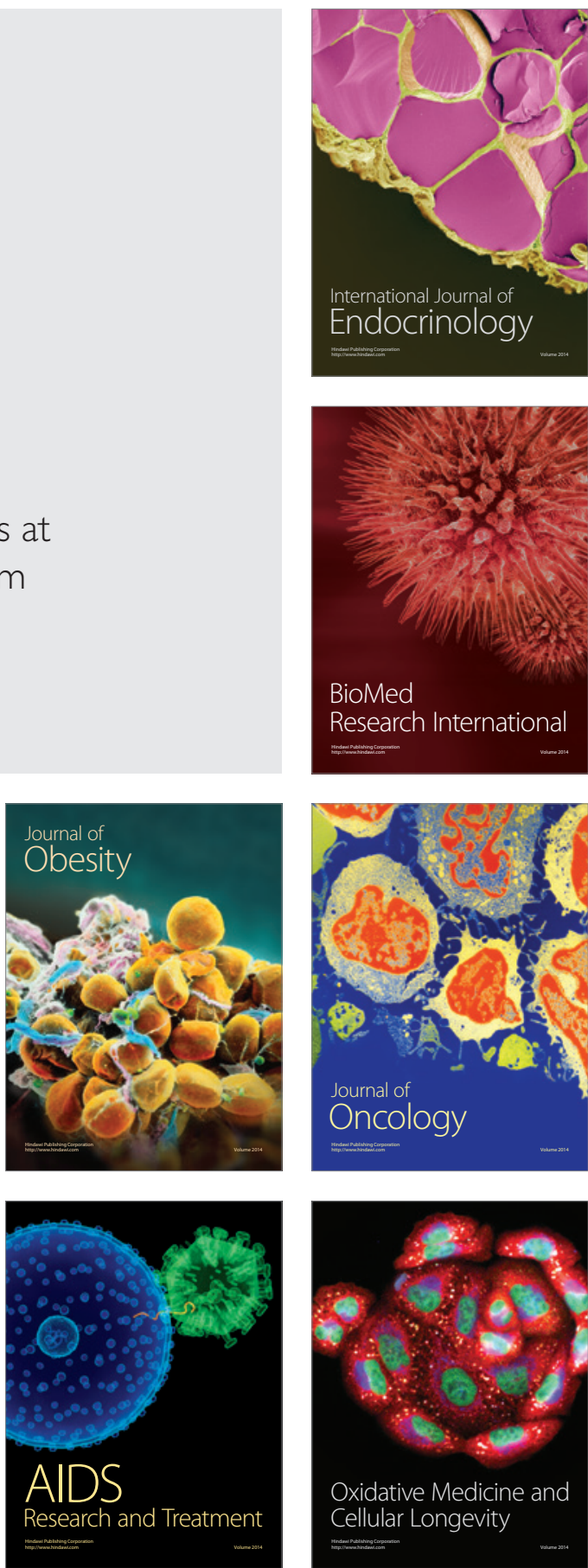